Brit. J. industr. Med., 1959, 16, 191.

\title{
BIOCHEMICAL STUDIES ON THE TOXICITY OF TETRAETHYL LEAD AND OTHER ORGANO-LEAD COMPOUNDS
}

\author{
BY \\ JILL E. CREMER \\ From the Toxicology Research Unit, M.R.C. Laboratories, Woodmansterne Road, Carshalton, Surrey
}

(RECEIVED FOR PUBLICATION OCTOBER 28, 1958)

The actions of purified tetra-, tri-, and di-ethyl lead on rats and rat brain slices and brain brei have been examined. A method based on a reaction with dithizone and capable of estimating triand di-ethyl tin in rat tissues has been developed.

After injection into rats tetraethyl lead is converted into triethyl lead and this is responsible for the toxic effects. Diethyl lead is much less toxic and the effects are different. The utilization of lactate and the oxidation of glucose by brain brei and slices respectively are inhibited by triethyl lead. A similar effect is seen in slices taken from rats poisoned with tetra- or tri-ethyl lead. Rat liver cell microsomes readily convert tetraethyl to triethyl lead and the latter is stable and remains in the animal tissues for several days. The concentration of triethyl lead in the brain is not high in comparison with other tissues but brain tissue appears to be unduly sensitive to its toxic action.

Neither tetra- nor tri-ethyl lead reacts with B.A.L. or ethylene-diamine-tetra-acetic acid (E.D.T.A.). Diethyl lead reacts with B.A.L. but not with E.D.T.A.

Tetraethyl lead has been added to petroleum as an anti-knock agent for many years and is known to be toxic to man. Casualties have usually occurred among persons cleaning out petrol tanks, and a very full account has been given by Cassells and Dodds (1946). The signs of poisoning indicate that the main site of action is the central nervous system; in severe cases tremors and convulsions develop, often leading to death. Similar signs can be produced by giving tetraethyl lead to laboratory animals.

In tetraethyl lead all valencies are satisfied. It is insoluble in water but soluble in ethanol and fat solvents. On exposure to intense daylight it decomposes and triethyl lead and diethyl lead can be detected as decomposition products. The ionic forms of the chloride salts of triethyl lead and diethyl lead are depicted below since they were used throughout the study to be described. Both are water soluble and ionize to give a mono-valent and di-valent ion respectively. None of these organolead compounds chelate with ethylene-diamine-<smiles>CCC[Pb](CC)(CC)CCCC[Te][Pb](CC)(CC)CC</smiles>

tetra-acetic acid (E.D.T.A.), whereas lead acetate chelates most readily.

Although it was suggested by Buck and Kumro (1930) and by Machle (1935) that the toxic action of tetraethyl lead might be due to its more watersoluble decomposition products rather than to the parent compound itself, there are no published data to support this idea. There is no information on the biochemical action of organo-lead compounds.

This paper describes some biochemical effects of tetra-, tri-, and di-ethyl lead and lead acetate on rat brain metabolism. A method has been developed for estimating tri- and di-ethyl lead as intact organolead ions in biological material and the presence of a system in rat liver capable of converting tetraethyl lead to triethyl lead has been shown.

\section{Methods}

Male adult albino rats of 175 to $230 \mathrm{~g}$. body weight maintained on M.R.C. diet No. 41B (Bruce and Parkes, 1956) were used.

Slices of brain cortex and liver were prepared using a Stadie-Riggs type slicer (Stadie and Riggs, 1944).

For studies on the metabolic activity of brain cortex slices, each Warburg flask contained $3 \mathrm{ml}$. of KrebsRinger phosphate solution (Umbreit, Burris, and Stauffer, 1951), with $0.011 \mathrm{M}$ glucose, tissue slice of 50 to $60 \mathrm{mg}$. wet weight, and $0.2 \mathrm{ml}$. of $20 \%(\mathrm{w} / \mathrm{v}) \mathrm{KOH}$ in the centre 
well for absorption of $\mathrm{CO}_{2}$. The manometers were placed in a water bath at $37^{\circ} \mathrm{C}$., gassed for $5 \mathrm{~min}$. with $100 \% \mathrm{O}_{2}$, equilibrated for a further $10 \mathrm{~min}$., and $\mathrm{O}_{2}$ uptake was measured at intervals up to $75 \mathrm{~min}$. $\mathrm{QO}_{2}$ was calculated as $\mu \mathrm{l}$. of $\mathrm{O}_{2} / \mathrm{mg}$. dry weight of tissue $/ \mathrm{hr}$. The control $\mathrm{QO}_{2}$ value was $13.26 \pm 1.14$ (S.D.). Lactic acid was estimated by the technique of Barker and Summerson (1941) and pyruvic acid by the method of Friedemann and Haugen (1943).

Rat Brain Brei.- The suspensions were prepared in ice-cold $0.1 \mathrm{M}$ phosphate buffer $p \mathrm{H} 7.4$ as previously described (Aldridge and Cremer, 1955).

Fractionation of Liver Homogenates.-This process was carried out essentially by the centrifugation techniques of Schneider (1948). A $10 \%(w / v)$ liver homogenate was prepared in $\mathbf{0 . 3} \mathrm{M}$ ice-cold sucrose. The nuclei and cellular debris were separated off by centrifuging at $600 \mathrm{~g}$. for $10 \mathrm{~min}$. at $0^{\circ} \mathrm{C}$. The mitochondria were sedimented at $7,500 \mathrm{~g}$. for $20 \mathrm{~min}$. The supernatant containing the microsomes and soluble cell material was separated into microsomes and clear supernatant by centrifuging at $105,000 \mathrm{~g}$. for $60 \mathrm{~min}$ at $0^{\circ} \mathrm{C}$. using a "spinco ultra" centrifuge.

Purification of Organo-lead Compounds.-Tetraethyl lead, triethyl lead chloride, and diethyl lead dichloride were supplied by Dr. Boyd. These compounds are unstable even when stored in subdued light and require purification before use. Tetraethyl lead was separated from traces of triethyl lead and diethyl lead by washing an ether solution with conductivity water three to four times in subdued light and allowing the ether to evaporate. The purified sample was stored in the dark at $-20^{\circ} \mathrm{C}$. A stock ethanolic solution of $40 \mathrm{mg}$. tetraethyl lead $/ \mathrm{ml}$. was prepared and stored in a blackened, stoppered tube at $0^{\circ} \mathrm{C}$. A fresh stock solution was prepared every four weeks. Triethyl lead chloride was purified by recrystallization from a large volume of ether in subdued light. Aqueous stock solutions of $10 \mathrm{mg} . / \mathrm{ml}$. were prepared every two weeks and were also stored in blackened, stoppered tubes at $0^{\circ} \mathrm{C}$. On storage of diethyl lead dichloride for several weeks triethyl lead could be detected together with water-insoluble material. It was purified by washing twice with ether to remove triethyl lead followed by recrystallization of diethyl lead dichloride from an ethanolic extract in subdued light. Fresh aqueous solutions were prepared just before each experiment.

Injections of Lead Compounds in Rats.-Tetraethyl lead was given by intravenous (tail vein) injection as solution in ethanol. Each rat received not more than $0 \cdot 1$ $\mathrm{ml}$.; triethyl lead chloride and diethyl lead dichloride were given by intraperitoneal injections as solutions in $0.9 \% \mathrm{NaCl}$. Lead acetate was given by intravenous injection as an aqueous solution. Each rat received not more than $0.2 \mathrm{ml}$. of a solution $100 \mathrm{mg}$. $/ \mathrm{ml}$.

Tissue Water Content of Brain and Spinal Cord.-The water content was taken as the difference between the wet weight and the dry weight after heating at $104^{\circ} \mathrm{C}$. Values in Table 9 are expressed as \% water in the original wet weight.

Estimation of Organo-lead Compounds.-The procedures used were based on the dithizone method for the estimation of triethyl tin in biological material described by Cremer (1957). For the estimation of triethyl lead, tissue samples of between 0.4 and $1.0 \mathrm{~g}$. wet weight were homogenized in $5 \mathrm{ml}$. water using a "nelco" homogenizer. Water $(15 \mathrm{ml}$.) was added to the homogenate and the protein was precipitated with perchloric acid $(30 \% \mathrm{v} / \mathrm{v}$; $5 \mathrm{ml}$.). The contents were mixed thoroughly and centrifuged for $10 \mathrm{~min}$. A $20 \mathrm{ml}$. sample of the supernatant was taken, neutralized with $5 \mathrm{~N} \mathrm{NaOH}$ (approximately $5.5 \mathrm{ml}$.) and $2 \mathrm{ml}$. of borate-E.D.T.A. buffer was added (19 g. of $\mathrm{Na}_{2} \mathrm{~B}_{4} \mathrm{O}_{7}, 10 \mathrm{H}_{2} \mathrm{O} ; 12 \mathrm{~g}$. of boric acid; 4 g. E.D.T.A. diluted to 1 litre).

The following procedures were carried out in a darkened room owing to the instability of the coloured complex to be formed. Chloroform $(10 \mathrm{ml}$.) was added followed by $1 \mathrm{ml}$. of dithizone reagent $0.04 \%(\mathrm{w} / \mathrm{v})$ dithiocarbazone in $\mathrm{CHCl}_{3}$ and the contents mixed thoroughly for $2 \mathrm{~min}$. using a mushroom-ended glass rod. The aqueous layer was removed by suction. The chloroform layer, containing the triethyl lead-dithizone complex, was read against a dithizone control in $2 \mathrm{~cm}$. cells at a wavelength of $610 \mathrm{~m} \mu$ using a "unicam" SP.600 spectrophotometer. Two drops of acetic acid (Analar) were then added to each tube (triethyl lead does not complex with dithizone under acid conditions) and readings taken again. The difference value of the two readings, giving the amount of dithizone used, was compared with the amount used by a standard concentration of triethyl lead. Recovery of triethyl lead added to $1 \mathrm{~g}$. wet weight samples of tissue was between 70 and $80 \%$. The values given in Tables 2, 3, and 9 for the amount of triethyl lead in the various tissues have been corrected for this recovery.

Tetraethyl lead does not form a coloured complex with dithizone. When triethyl lead was estimated in the presence of tetraethyl lead, owing to the instability of the latter compound in an acid medium, the protein was precipitated by adding $\mathrm{Ba}(\mathrm{OH})_{2}(0.3 \mathrm{~N} ; 5 \mathrm{ml}$.) and $\mathrm{ZnSO}_{4}\left[5 \cdot 35 \%(\mathrm{w} / \mathrm{v}) \mathrm{ZnSO}_{4} \cdot 7 \mathrm{H}_{2} \mathrm{O} ; 5 \mathrm{ml}\right.$.] to the tissue homogenate in $15 \mathrm{ml}$. water. After centrifuging, a $20 \mathrm{ml}$. sample of the supernatant was taken and $2.0 \mathrm{ml}$. of borate-E.D.T.A. buffer was added. The procedure was then exactly as described above.

Using the procedures described above recoveries of diethyl lead from tissues except blood were low, and the results obtained are of qualitative value only. From blood $90 \%$ diethyl lead was recovered.

\section{Results}

Action of Lead Compounds in Rats.-Although there have been reports of experimental organo-lead poisoning (Harnack, 1878; Mason, 1921; Bischoff, Maxwell, Evans, and Nuzum, 1928; Buck and Kumro, 1930; Kehoe and Thamann, 1931; Mortensen, 1942; and Morelli and Preziosi, 1953) few comparisons of different organo-lead compounds in the same species have been made. Therefore, the four lead compounds, tetra-, tri-, and di-ethyl lead, and lead acetate, were given to rats and the main symptoms observed are recorded in Table 1 . The routes of administration were as described under Methods. 
TABLE 1

ACTION OF LEAD COMPOUNDS IN RATS IN VIVO

\begin{tabular}{|c|c|c|c|c|c|c|c|}
\hline \multirow{2}{*}{ Compound } & \multirow{2}{*}{$\begin{array}{l}\text { Dose (mg./kg. } \\
\text { body weight) }\end{array}$} & \multirow{2}{*}{ Route } & \multirow{2}{*}{$\begin{array}{l}\text { Number } \\
\text { of Rats }\end{array}$} & \multicolumn{3}{|c|}{ Symptoms } & \multirow{2}{*}{ Death } \\
\hline & & & & Excitable & Tremors & Convulsions & \\
\hline $\begin{array}{l}\text { Tetraethyl lead } \\
\text { Triethyl lead } \\
\text { Diethyl lead } \\
\text { Lead acetate }\end{array}$ & $\begin{array}{l}20 \\
15 \cdot 4 \\
15 \\
11 \cdot 2 \\
40 \\
20 \\
100\end{array}$ & $\begin{array}{l}\text { Intravenous } \\
\text { Intraperitoneal } \\
\text { Intrapëritoneal } \\
\text { Intrave"nous }\end{array}$ & $\begin{array}{l}4 \\
4 \\
4 \\
4 \\
2 \\
2 \\
4\end{array}$ & $\begin{array}{c}++++ \\
++++ \\
++++ \\
++++ \\
\text { Slight loss of } \\
\text { weight } \\
\text { Loss of } \\
\text { weight }\end{array}$ & $\begin{array}{l}++++ \\
++++ \\
++\end{array}$ & $\begin{array}{l}++ \\
++++\end{array}$ & $\begin{array}{l}4 \\
0 \\
4 \\
2 \\
0 \\
0 \\
0\end{array}$ \\
\hline
\end{tabular}

TABLE 2

ACTIVITY OF BRAIN SLICES FROM RATS GIVEN LEAD COMPOUNDS

\begin{tabular}{|c|c|c|c|c|c|c|c|c|c|}
\hline \multirow{2}{*}{ Compound } & \multirow{2}{*}{$\underset{\text { (mg./kg.) }}{\text { Dose }}$} & \multirow{2}{*}{$\begin{array}{c}\text { Time after } \\
\text { Injection } \\
\text { (hr.) }\end{array}$} & \multicolumn{3}{|c|}{ Brain Slices ( $\%$ of Control) } & \multicolumn{4}{|c|}{ Tri-ethyl Lead Found ( $\mu \mathrm{g} \cdot / \mathrm{g}$. wet wt.) } \\
\hline & & & $\mathrm{QO}_{2}$ & Lactic Acid & Pyruvic Acid & Blood & Liver & Kidney & Brain \\
\hline Triethyl lead chloride & $\begin{array}{l}20 \\
20 \\
10 \\
10 \\
10 \\
10\end{array}$ & $\begin{array}{r}4 \\
24 \\
4 \\
24 \\
4 \\
24\end{array}$ & $\begin{array}{l}50 \\
33 \\
80 \\
60 \\
54 \cdot 5 \\
53\end{array}$ & $\begin{array}{l}295 \\
280 \\
150 \\
235 \\
330 \\
300\end{array}$ & $\begin{array}{l}46 \\
36 \\
88 \\
71 \cdot 5 \\
58 \cdot 5 \\
52\end{array}$ & $\begin{array}{c}76 \\
62 \\
12 \\
12 \\
65 \\
35 \\
\end{array}$ & $\begin{array}{l}45 \\
29 \\
15 \cdot 5 \\
20 \\
39 \\
30\end{array}$ & $\begin{array}{l}23 \\
25 \\
10 \\
10 \\
24 \\
19\end{array}$ & $\begin{array}{r}2 \cdot 4 \\
19 \cdot 0 \\
- \\
4 \\
8\end{array}$ \\
\hline
\end{tabular}

*These values are from different animals.

After receiving either tetra- or tri-ethyl lead the signs of poisoning which developed were identical. With lethal doses of either compound the rats became quiet and uneasy immediately after injection. Sometimes they gasped during the first half-hour. Twentyfour hours later the rats behaved very excitably, especially in their reactions to sudden noise and movement in the proximity of their cage. They remained in an excitable state and during the following 24 hours they developed in addition severe continuous tremors generalized throughout the body. This stage was often accompanied by violent, intermittent convulsions leading to death. After the highest doses given (tetraethyl lead $26 \mathrm{mg} . / \mathrm{kg}$. body weight and triethyl lead chloride $33 \mathrm{mg} . / \mathrm{kg}$.) death never occurred in less than 24 hours and after tetraethyl lead deaths might not take place for up to 14 days. Rats given just sublethal doses also became very excitable and developed a continuous tremor of the lower jaw only. Sometimes pairs of rats were observed to be standing facing each other as if sparring. Similar behaviour was reported by Stoner, Barnes, and Duff (1955) in rats given trimethyl tin acetate. The only difference observed between tetra- and tri-ethyl lead in their action on rats was the dose required to produce identical symptoms. The LD50 value was $11 \cdot 2$ (9.6 to $13 \cdot 6)$ mg./kg. body weight for triethyl lead chloride and $15.4(13.2$ to 18.0$) \mathrm{mg} . / \mathrm{kg}$. for tetraethyl lead calculated by the method of Weil (1952).
Rats given diethyl lead dichloride intraperitoneally in doses of 20 and $40 \mathrm{mg}$./kg., apart from initial uneasiness and loss of appetite during the first few days, did not behave differently from the controls over a 12-week observation period. Similar results were found in rats given lead acetate intravenously in a dose of $100 \mathrm{mg}$. $/ \mathrm{kg}$., although the initial loss in body weight was more pronounced. Four $200 \mathrm{~g}$. male rats lost an average of $30 \mathrm{~g}$. each during the first four days but steadily gained weight from the second week onwards.

Distribution of Organo-lead Compounds in Rats.In the Methods section a procedure is described for the estimation of triethyl lead, as the complete organic lead ion, in biological material. The method is based on the coloured complex between dithizone and organo-lead compounds. Tetraethyl lead does not react and the complex with triethyl lead may be distinguished from the diethyl lead complex by its absorption spectrum. The method may therefore be made specific for triethyl lead.

The distribution and amount of triethyl lead in certain tissues of rats killed at $4 \mathrm{hr}$. and $24 \mathrm{hr}$. after intraperitoneal injections of triethyl lead chloride are given in Table 2. The highest concentrations were found in whole blood. When analyses were made on separated plasma and erythrocytes over $90 \%$ of the triethyl lead was found in the erythrocytes. Liver and kidney also contained appreciable quantities of triethyl lead but a lower concentration 
was found in the brain. Unlike the results in the other three tissues the amount of triethyl lead found in the brain increased over a 24-hr. period but longer time intervals were not studied. After the administration of tetraethyl lead to rats considerable quantities of triethyl lead were found in the tissues. The pattern of distribution of the triethyl lead was virtually identical to that found after injections of triethyl lead. Again the amount found in brain was less than that found in other tissues.

To determine the stability and persistence of triethyl lead in rat tissues in vivo a group of five rats was given triethyl lead chloride, $10 \mathrm{mg}$. $/ \mathrm{kg}$. intraperitoneally, and killed at intervals between two hours and four days. The tissues were removed for analysis of triethyl lead. The results in Table 3 show that the level of this compound remained almost unaltered during this time. This persistence may account for the late deaths after single doses.

TABLE 3

PERSISTENCE OF TRIETHYL LEAD IN RATS IN VIVO

\begin{tabular}{|c|c|c|c|c|c|c|}
\hline \multirow{2}{*}{$\begin{array}{c}\text { Time } \\
\text { Killed } \\
\text { after } \\
\text { Injection } \\
\text { (hr.) }\end{array}$} & \multicolumn{3}{|c|}{$\begin{array}{l}\text { Brain Cortex Slices } \\
\text { (\% of controls) }\end{array}$} & \multicolumn{3}{|c|}{ 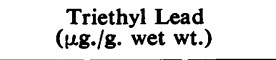 } \\
\hline & $\mathrm{QO}_{2}$ & $\begin{array}{l}\text { Lactic } \\
\text { Acid }\end{array}$ & $\begin{array}{c}\text { Pyruvic } \\
\text { Acid }\end{array}$ & Blood & Liver & Kidney \\
\hline $\begin{array}{r}2 \\
4 \\
24 \\
48 \\
96\end{array}$ & $\begin{array}{r}100 \\
55 \\
53 \\
43 \\
56\end{array}$ & $\begin{array}{l}125 \\
330 \\
300 \\
292 \\
270\end{array}$ & $\begin{array}{l}95 \\
60 \\
53 \\
51 \\
64\end{array}$ & $\begin{array}{l}57 \\
65 \\
35 \\
43 \\
39\end{array}$ & $\begin{array}{l}36 \\
39 \\
30 \\
29 \\
22\end{array}$ & $\begin{array}{l}17 \\
24 \\
19 \\
26 \\
19\end{array}$ \\
\hline
\end{tabular}

Triethyl lead chloride, $10 \mathrm{mg}$./kg., was given by intraperitoneal injection.

As stated previously, the recovery of diethyl lead from biological material is low except from blood. Estimations of diethyl lead in blood samples taken from rats which had been given diethyl lead dichloride were made and the results, given in Table 2 , indicate that diethyl lead can be found in high con centrations as the intact ion $\mathbf{2 4}$ hours after injection.

Conversion of Tetra- to Tri-ethyl Lead.-In previous studies in this laboratory (Cremer, 1958) it was shown that the conversion of tetra- to triethyl tin could be brought about by rat liver in vitro.

Therefore several tissues were examined in vitro for their ability to convert tetraethyl lead to triethyl lead and the liver was found to be highly active, while negligible activity was found in kidney and brain. When rat liver slices were incubated with tetraethyl lead the amount of triethyl lead produced was proportional to the wet weight of liver used. The rate of production of triethyl lead by liver slices is shown in Fig. 1. This rate of conversion of tetra- to tri-ethyl lead could account for the amount of triethyl lead found in the tissues of rats four hours after an injection of tetraethyl lead (Table 2) asuming that the conversion took place in the liver from

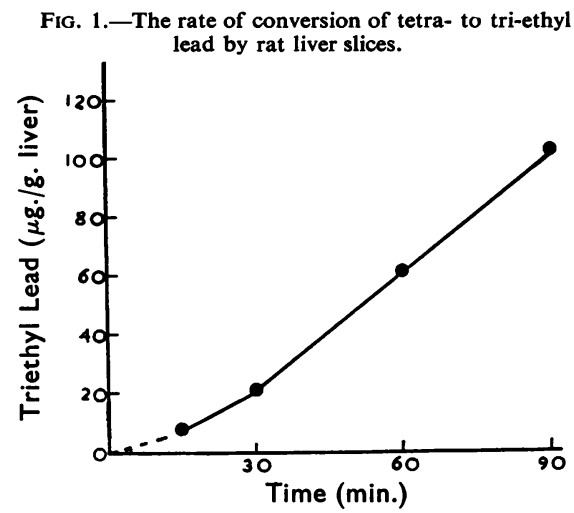

where the triethyl lead formed was distributed throughout the body.

During the past few years several detailed studies have been made on the metabolism of a wide variety of foreign substances by liver preparations (see review by Brodie, 1956). The main factor in common is that the microsomal fraction plus soluble material of the liver cell appears to be the site of activity. The exact location of the active principles concerned is not known, but the major portion of the activity is found in the supernatant remaining after larger particles, which include nuclei and mitochondria, have been removed. The supernatant contains the microsomes and watersoluble cell constituents. Experiments have been carried out on the conversion of tetra- to tri-ethyl lead using fractions of liver homogenates prepared by the usual centrifugation techniques as described in Methods. The distribution of activity is given in Table 4 which shows that the major portion of it was in the microsomes plus soluble material of the cell. When separated fractions of liver cells are used the conversion activity is enhanced by the addition of several fortifying constituents. The maximum activity was obtained with the conditions described in the legend to Table 4. No conversion took place

TABLE 4

DISTRIBUTION IN RAT LIVER CELLS OF SYSTEM CONVERTING TETRAETHYL LEAD TO TRIETHYL LEAD

\begin{tabular}{l|c}
\hline \multicolumn{1}{c|}{ Liver Fraction } & Activity (\%) \\
\hline Whole homogenate & 100 \\
Cell debris + nuclei & 0 \\
Washed mitochondria & $0 \cdot 4$ \\
Microsomes + soluble material & $94 \cdot 5$ \\
Unwashed microsomes & 3 \\
Soluble material & $1 \cdot 3$ \\
\hline
\end{tabular}

Each flask contained a sample $(2 \mathrm{ml}$.) of liver cell fraction in $0.3 \mathrm{M}$ sucrose, tetraethyl lead $0.0007 \mathrm{M}, \mathrm{MgSO}_{4} 0.018 \mathrm{M}$, nicotinamide $0.008 \mathrm{M}$, triphosphopyridine nucleotide $0.00014 \mathrm{M}$, and phosphate buffer $0.016 \mathrm{M}$ final concentrations in a total volume of $3.0 \mathrm{ml}$. with the $p \mathrm{H}$ adjusted to 6.9. Incubation was at $37^{\circ} \mathrm{C}$. in $\mathrm{O}$, for 90 min., and determinations of triethyl lead were then made. The activity of the whole homogenate, taken as $100 \%$, was $190 \mu$ g. triethyl lead/g. wet wt./hr. 
in an atmosphere of $95 \% \mathrm{~N}_{2}+5 \% \mathrm{CO}_{2}$ and the reaction was inhibited by the substance SKF525A (diethylamino ethyl diphenyl propylacetate), well known for its ability to inhibit the metabolism of drugs by liver microsomes (Brodie, 1956).

The results from experiments carried out in vitro thus confirm that rat liver has the ability to convert tetra- to tri-ethyl lead.

Effect of Lead Compounds on Rat Brain Metabolism in vitro.-From the studies of the different lead compounds on rats in vivo it was evident that tetra- and tri-ethyl lead produced identical signs of poisoning while diethyl lead and lead acetate were very much less toxic. Biochemical studies on the effect of these lead compounds on the metabolism of brain preparations in vitro were performed in an attempt to throw some light on observations made in vivo.

Experiments with Rat Brain Brei.-First, experiments were carried out using rat brain brei. This type of preparation consists of a mixture of small clumps of whole, isolated, and disintegrated cells. The preparation actively metabolizes lactic acid, oxidizing it via pyruvic acid. An interference in the lactate metabolism is reflected by an alteration in the $\mathrm{O}_{2}$ consumption and in the level of pyruvate.

The effect of different lead compounds on the utilization of lactate by rat brain brei preparations was examined. Earlier studies by Aldridge and Cremer (1955) showed that by using this technique a difference between the biochemical action of diethyl tin and triethyl tin could be readily detected. They found that concentrations of diethyl tin which lowered $\mathrm{O}_{2}$ uptake led to an accumulation of pyruvate and in this respect resembled arsenious acid and phenylarsenious acid. Triethyl tin, on the other hand, lowered both $\mathrm{O}_{2}$ uptake and the pyruvate level. Table 5 shows the results obtained with the lead compounds. Both tetraethyl lead and lead acetate were without effect. Diethyl lead, like diethyl tin, caused an accumulation of pyruvate
TABLE 5

EFFECT OF LEAD COMPOUNDS ON RAT BRAIN BREI PREPARATIONS OXIDIZING LACTATE

\begin{tabular}{c|c|c|c}
\hline Lead Compound & $\begin{array}{c}\text { Concentration } \\
(\mathbf{M})\end{array}$ & $\begin{array}{c}\mathrm{O}_{2} \text { Uptake } \\
(\% \text { of control) }\end{array}$ & $\begin{array}{c}\text { Pyruvate } \\
\text { Level } \\
\text { \% of control) }\end{array}$ \\
\hline Tetraethyl lead & $7 \times 10^{-4}$ & 100 & 86.5 \\
Triethyl lead & $9 \times 10^{-5}$ & 100 & 97 \\
& $4.6 \times 10^{-4}$ & 64 & 146 \\
Diethyl lead & $1.5 \times 10^{-4}$ & 76.5 & 58 \\
& $5.2 \times 10^{-5}$ & 91 & 72 \\
Lead acetate & $3.3 \times 10^{-4}$ & 30 & 432 \\
\hline
\end{tabular}

Each flask contained lithium lactate $0.015 \mathrm{M}$, brei equivalent to $17 \mathrm{mg}$. wet weight of original brain, and inhibitor as indicated. The final volume was made up to $3 \mathrm{ml}$. with $0 \cdot 1 \mathrm{M}$ phosphate buffer pH 7.4. The centre well contained $0.15 \mathrm{ml} .20 \%(\mathrm{w} / \mathrm{v}) \mathrm{KOH}$ for $\mathrm{CO}_{2}$ absorption. The gas phase was air and the temperature $37^{\circ} \mathrm{C}$. After $10 \mathrm{~min}$. equilibration readings were taken every $10 \mathrm{~min}$, up to $50 \mathrm{~min}$. At the end of the experiment $3 \mathrm{ml} .18 \%(\mathrm{w} / \mathrm{v})$ TCA was added to each flask and $3 \mathrm{ml}$. samples taken for the estimation of pyruvate.

when $\mathrm{O}_{2}$ uptake was lowered. The effect of triethyl lead was less clear cut. At high concentrations the $\mathrm{O}_{2}$ uptake was lowered and there was a small increase in the pyruvate level. At lower concentrations, which still inhibited $\mathrm{O}_{2}$ uptake, the pyruvate level was decreased. The effects obtained using either di- or tri-ethyl lead at $1 \times 10^{-4} \mathrm{M}$ concentration show that there is a distinct difference between the mode of action of the two compounds.

Diethyl tin has been shown to resemble phenylarsenious acid and lewisite (Stocken and Thompson, 1946) in its avid reaction with B.A.L. but only slight affinity for glutathione (Aldridge and Cremer, 1955). The effect of several SH compounds on the oxidation of lactate by rat brain brei in the presence of di- and tri- ethyl lead has been studied and the results are given in Table 6 . The effects of diethyl lead were completely prevented by B.A.L. and almost completely prevented by thioglycollic acid whereas glutathione had only a slight effect. On the other hand these thiol compounds had no effect upon the action of triethyl lead.

TABLE 6

EFFECT OF SH COMPOUNDS ON OXIDATION OF LACTATE BY RAT BRAIN BREI IN PRESENCE OF DI- AND TRI- ETHYL LEAD

\begin{tabular}{|c|c|c|c|c|c|c|}
\hline \multirow{2}{*}{$\begin{array}{c}\text { Concentration of } \\
\text { Organo-lead Compound } \\
\text { (M) }\end{array}$} & \multirow[b]{2}{*}{ Concentration $\underset{(\mathbf{M})}{\text { of }}$ SH Compound } & \multirow[b]{2}{*}{$\mathbf{R}$} & \multicolumn{2}{|c|}{$\begin{array}{l}\mathrm{O}_{2} \text { Uptake } \\
(\% \text { of control) }\end{array}$} & \multicolumn{2}{|c|}{$\begin{array}{l}\text { Pyruvate } \\
\text { (\% of control) }\end{array}$} \\
\hline & & & Inhibitor & $\begin{array}{c}\text { Inhibitor } \\
+ \text { SH } \\
\text { Compound }\end{array}$ & Inhibitor & $\begin{array}{l}\text { Inhibitor } \\
+ \text { SH } \\
\text { Compound }\end{array}$ \\
\hline $\begin{aligned} & \text { Diethyl lead } 1.1 \times 10^{-4} \times 1.1 \times 10^{-4} \\
& 1.1 \times 10^{-4} \\
& \text { Triethyl lead } 2.5 \times 10^{-4} \\
& 2.5 \times 10^{-4} \\
& 2.5 \times 10^{-4}\end{aligned}$ & $\begin{array}{r}\text { B.A.L. 2.8 } \times 10^{-4} \\
\text { Thioglycollic acid } 3.7 \times 10^{-4} \\
\text { Glutathione } 6 \times 10^{-4} \\
\text { B.A.L. } 3 \times 10^{-4} \times 10^{-4} \\
\text { Thioglycollic acid } 3.0 \times 10^{-4} \\
\text { Glutathione } 3.8 \times 10^{-4}\end{array}$ & $\begin{array}{l}2 \cdot 5 \\
3 \cdot 4 \\
5 \cdot 5 \\
1 \cdot 2 \\
1 \cdot 2 \\
1 \cdot 5\end{array}$ & $\begin{array}{l}49 \\
52 \\
43 \\
76 \\
76 \\
72\end{array}$ & $\begin{array}{l}100 \\
81 \cdot 5 \\
56 \\
77 \\
68 \\
72\end{array}$ & $\begin{array}{r}298 \\
278 \\
408 \\
69 \\
67 \\
58\end{array}$ & $\begin{array}{r}100 \\
117 \\
246 \\
80 \\
61 \\
50\end{array}$ \\
\hline
\end{tabular}

The procedure was the same as described for Table 1. SH compounds and the organo-lead compounds were added as indicated and left $10 \mathrm{~min}$. at room temp. before $1 \mathrm{ml}$. of brain brei was added. $\mathbf{R}$ is the quotient of the molar concentration of SH compound/molar concentration of organo-lead compound. 
Experiments with Slices of Rat Brain Cortex.Preparations of rat-brain cortex slices have also been used. The slices were incubated in Krebs-Ringer phosphate medium with glucose as substrate. As with the rat brain brei experiments, any alteration in the $\mathrm{O}_{2}$ consumption or levels of intermediate compounds normally present during the oxidation of glucose is indicative of a biochemical lesion.

The effects of the four lead compounds on this system were studied (Table 7). The most active was

TABLE 7

EFFECT OF LEAD COMPOUNDS ADDED IN VITRO ON METABOLISM OF SLICES OF RAT BRAIN CORTEX

\begin{tabular}{|c|c|c|c|c|}
\hline \multirow{2}{*}{ Lead Compound } & \multirow{2}{*}{$\begin{array}{l}\text { Concentra- } \\
\text { tion (M) }\end{array}$} & \multicolumn{3}{|c|}{$\%$ of Control } \\
\hline & & $\mathbf{Q O}_{2}$ & $\begin{array}{l}\text { Lactic } \\
\text { Acid }\end{array}$ & $\begin{array}{c}\text { Pyruvic } \\
\text { Acid }\end{array}$ \\
\hline $\begin{array}{l}\text { Tetraethyl lead } \\
\text { Triethyl lead } \\
\text { +E.D.T.A. } 8 \times 10^{-5} \mathrm{M} \\
\text { Diethyl lead } \\
\text { Lead acetate }\end{array}$ & $\begin{array}{l}2 \times 10^{-4} \\
7 \times 10^{-5} \\
2 \times 10^{-6} \\
7 \times 10^{-7} \\
7 \times 10^{-7} \\
1 \times 10^{-5} \\
3 \times 10^{-6} \\
2 \times 10^{-6}\end{array}$ & $\begin{array}{l}90 \\
100 \\
45 \cdot 5 \\
86 \\
86 \\
42 \\
100 \\
100\end{array}$ & $\begin{array}{l}163 \\
100 \\
355 \\
285 \\
315 \\
153 \\
110 \\
110\end{array}$ & $\begin{array}{r}88 \\
100 \\
38 \\
66 \\
51 \\
48 \\
82 \\
100\end{array}$ \\
\hline
\end{tabular}

The control values for lactic acid and pyruvic acid were $193 \mu \mathrm{g}$. and $11 \mu \mathrm{g}$. respectively, estimated as the amount present in the medium after $75 \mathrm{~min}$. incubation, and E.D.T.A. was added as ethylenediamine-tetra-acetic acid disodium salt.

triethyl lead, which caused a lowering of the $\mathrm{O}_{2}$ consumption and the pyruvate level with an increase in the lactate level. This effect was identical with that previously shown for triethyl tin (Cremer, 1957). The altered metabolic pattern suggested that the oxidation of pyruvate to $\mathrm{CO}_{2}$ and water was impaired and that the system had become partially anaerobic causing pyruvic acid to be reduced to lactic acid which accumulated. During the complete oxidation of glucose the major part of the synthesis of energy-yielding substances, in particular phosphocreatine and adenosine triphosphate, occurs during the oxidation of pyruvate via the tricarboxylic acid cycle.

There was an interesting difference between the sensitivity of brain brei preparations and brain slices to triethyl lead. Brain slices were over a hundred times more sensitive. Although the reason for this difference is not understood it is an important factor to be borne in mind when testing the action of toxic substances in vitro. Unpublished observations by W. N. Aldridge in these laboratories indicate that oxidation coupled to phosphorylative processes of isolated rat liver mitochondrial preparations is sensitive to triethyl lead at a concentration of $5 \times 10^{-7} \mathrm{M}$.

Tetraethyl lead was without effect except at concentrations over a hundred times greater than those of triethyl lead. The small activity at these higher concentrations might have been due to traces of triethyl lead as a contaminant.
Diethyl lead was less active than triethyl lead. A distinguishing feature between the two compounds was that when the $\mathrm{O}_{2}$ uptake was inhibited and the pyruvate lowered by either compound the concomitant increase in lactic acid was always far greater in the presence of triethyl lead. Lead acetate was without effect.

Activity of Brain Slices Prepared from Rats Given Lead Compounds.-Slices were prepared from the brains of rats given lead compounds and their metabolic activities are recorded in Table 2 . There was a marked alteration in the metabolism of brain slices taken from rats which had been given tetraethyl lead and triethyl lead. The inhibition of the $\mathrm{O}_{2}$ uptake, increase in lactate, and decrease in pyruvate was identical with that of brain slices to which triethyl lead was added in vitro (Table 7). Estimations were also made of the amount of organolead compounds in some of the tissues of these animals. There was quite a close correlation between the amount of triethyl lead in the tissues and the extent of alteration in the metabolism of brain slices after administering either tetra- or tri-ethyl lead. An important difference between the two is that nearly double the dose of tetraethyl lead was required to produce effects equivalent to those of triethyl lead. In an attempt to confirm whether, in each case, the altered metabolism of the brain slices was due to the presence of triethyl lead, separate groups of rats were injected with either tetra- or tri-ethyl lead and brains removed for triethyl lead analysis. Although the amount found in the brain is low compared with other tissues, since brain slices are very sensitive to triethyl lead, the amount of this substance in the brain in vivo is sufficient to account for the altered metabolic activity seen in vitro. This is shown more clearly in Table 8 where the concentrations have been expressed as molarity. The assumption has

TABLE 8

COMPARISON OF ACTIVITY OF BRAIN SLICES WITH TRIETHYL LEAD ADDED IN VITRO AND SLICES FROM RATS GIVEN EITHER TETRA- OR TRI-ETHYL LEAD IN VIVO

\begin{tabular}{|c|c|c|c|c|}
\hline \multirow{2}{*}{$\begin{array}{l}\text { Route of Administra- } \\
\text { tion of Organo-lead } \\
\text { Compound }\end{array}$} & \multirow{2}{*}{$\begin{array}{c}\text { Concentration } \\
\text { of Triethyl } \\
\text { Lead in Brain } \\
\text { Tissue Fluid } \\
\text { (M) }\end{array}$} & \multicolumn{3}{|c|}{$\begin{array}{l}\text { Brain Cortex Slices } \\
\text { (\% of control) }\end{array}$} \\
\hline & & $\mathrm{QO}_{2}$ & $\begin{array}{l}\text { Lactic } \\
\text { Acid }\end{array}$ & $\begin{array}{c}\text { Pyruvic } \\
\text { Acid }\end{array}$ \\
\hline $\begin{array}{l}\text { Triethyl lead in vitro } \\
\text { Triethyl lead in vivo } \\
\text { Tetraethyl lead in vivo }\end{array}$ & $\begin{array}{l}1.6 \times 10^{-5} \\
4.6 \times 10^{-5} \\
1.8 \times 10^{-5} \\
3.4 \times 10^{-5} \\
1.02 \times 10^{-5} \\
8.15 \times 10^{-5}\end{array}$ & $\begin{array}{l}86 \\
45 \cdot 5 \\
54 \cdot 5 \\
53 \\
50 \\
33\end{array}$ & $\begin{array}{l}285 \\
355 \\
330 \\
300 \\
295 \\
280\end{array}$ & $\begin{array}{l}66 \\
38 \\
58 \cdot 5 \\
52 \\
46 \\
36\end{array}$ \\
\hline
\end{tabular}

been made that all triethyl lead found is in the tissue fluid of the brain, taking this value as $80 \%$ of the wet weight. Unpublished observations have shown that when brain slices are incubated with triethyl lead in vitro the concentration found within the 
slice is 23 times greater than that originally added in the medium. This factor has been used to calculate the amount of triethyl lead in the tissue fluid of brain slices when added in vitro. The metabolic activities are taken from Tables 2 and 7. Although the results show a good correlation, the values for the data in vivo are necessarily only approximate because of the assumptions which have been made in the calculation and the use of different groups of rats.

There was some alteration in the metabolism of brain slices taken from rats given diethyl lead dichloride, $40 \mathrm{mg}$. $/ \mathrm{kg}$., when killed after 24 hours. The effect was less marked than those of triethyl lead. After a dose of $20 \mathrm{mg}$. $/ \mathrm{kg}$. the values were no different from the controls (Table 2).

The metabolic pattern of brain slices prepared from rats given lead acetate, $100 \mathrm{mg} . / \mathrm{kg}$., was different inasmuch as there was a small but consistent increase in both the lactate and pyruvate levels without any alteration in the $\mathrm{O}_{2}$ consumption.

Since rats injected with lead acetate lost weight, which might have been due to a reduction in food intake or poor utilization of ingested food, the activity of brain slices prepared from rats which had been starved for 48 hours was examined. Their metabolic activity was identical with that of slices prepared from fed animals.

Tissue Water Content of Brain and Spinal Cord in Rats Given Triethyl Lead.-A striking feature of rats given tetra- or tri-ethyl tin either in single doses or by addition to the diet is the development of an oedematous lesion in the white matter of the brain and spinal cord. The experimental production of this lesion has been fully described by Magee, Stoner, and Barnes (1957) and a relationship was inferred between the presence of oedema and the alteration of brain metabolism (Cremer, 1957). Owing to the similarity between triethyl tin and triethyl lead in their action on rat brain metabolism it was of interest to know whether triethyl lead caused a similar type of lesion.

A group of eight rats was given $2 \mathrm{mg} . / \mathrm{kg}$. triethyl lead chloride intraperitoneally every four days for 36 days. Rats were killed in pairs between one and five weeks and the time was selected so that three days had elapsed since the last injection for each group. Brain slices were prepared from one half for the determination of metabolic activity and the water content determined on the other half. The amount of triethyl lead in the tissues was also measured (Table 9). There was no change in the water content of either the brain or spinal cord of rats given chronic injections of triethyl lead but there was a marked effect on the metabolism of brain slices.

Histological examination of the spinal cords of these animals did not reveal any pathological changes.

\section{Discussion}

Throughout reports in the literature on tetraethyl lead poisoning there are conflicting views on whether tetraethyl lead has an action peculiar to its organic nature or whether it acts solely by virtue of its lead content, the only difference from inorganic lead being the ease by which lead in an organic form is absorbed.

The reports by Cassells and Dodds (1946) of 25 cases of tetraethyl lead poisoning showed that the predominant symptoms were disturbances in the central nervous system, low blood pressure, and lowered body temperature. Abdominal colic, stippling of the red cells, and punctate basophilia, well known symptoms of inorganic lead poisoning, were seldom seen. Symptoms developed within a few days after exposure and unless death occurred during this acute period recovery was fairly rapid and complete.

These authors state that "the toxicity of tetraethyl lead is a function of the lead content and not of any peculiar qualities characteristic of the compound, but its fat-soluble character allows selective localization in the nervous tissue of the body and for this reason poisoning is essentially a central nervous system intoxication." The results reported in the present work are in conflict with both of these concepts.

Although the rat is the only species of animal which has been used, and it was shown by Calvery, Laug, and Morris (1938) that the rat is relatively insensitive to experimental inorganic lead poisoning, tetraethyl lead poisoning in the rat closely resembles that described for humans.

The symptoms observed in rats injected with the

TABLE 9

WATER CONTENT OF BRAIN AND SPINAL CORD OF RATS GIVEN CHRONIC INJECTIONS OF TRIETHYL LEAD

\begin{tabular}{|c|c|c|c|c|c|c|c|c|}
\hline \multirow{2}{*}{$\begin{array}{l}\text { Duration of } \\
\text { Injections } \\
\text { (weeks) }\end{array}$} & \multicolumn{2}{|c|}{ Water Content } & \multicolumn{3}{|c|}{ Brain Slices ( $\%$ of control) } & \multicolumn{3}{|c|}{ Triethyl Lead ( $\mu \mathrm{g} . / \mathrm{g})}$. \\
\hline & Brain & Spinal Cord & $\mathrm{QO}_{2}$ & Lactic Acid & Pyruvic Acid & Blood & Liver & Kidney \\
\hline $\begin{array}{c}\text { Control } \\
1 \\
2 \\
3 \\
5\end{array}$ & $\begin{array}{l}77 \cdot 2 \\
78 \\
77 \cdot 4 \\
77 \cdot 4\end{array}$ & $\begin{array}{l}69 \\
71 \cdot 7 \\
69 \cdot 8 \\
69 \cdot 8\end{array}$ & $\begin{array}{l}60 \\
51 \\
47 \\
46\end{array}$ & $\begin{array}{l}211 \\
201 \\
208 \\
254\end{array}$ & $\begin{array}{l}48 \\
41 \\
48 \\
46\end{array}$ & $\begin{array}{l}17 \\
24 \\
26 \\
32\end{array}$ & $\begin{array}{l}23 \\
27 \\
30 \\
37\end{array}$ & $\begin{array}{l}14 \\
19 \\
18 \\
23\end{array}$ \\
\hline
\end{tabular}


different lead compounds confirmed the findings of Buck and Kumro (1930) that those which develop after tetraethyl lead and triethyl lead are identical and differ from those of diethyl lead and lead acetate.

The concept that the predominance of nervous symptoms is due to the fat-soluble nature of tetraethyl lead causing it to be selectively localized in nervous tissue has not been supported by analytical data. Kehoe and Thamann (1931) found that in rabbits, after the application of tetraethyl lead to the skin, although there was complete absorption, no volatile lead (tetraethyl lead) was found in the central nervous system, but after three hours nonvolatile lead began to accumulate. Mortensen (1942) found that the small amount of volatile lead originally present in the brains of rats after inhalation of tetraethyl lead vapour completely disappeared within a few hours.

Several workers have suggested that tetraethyl lead is rapidly broken down in the tissues to watersoluble, non-volatile products (Kehoe and Thamann, 1931; Machle, 1935; Mortensen, 1942). The development of a method using dithizone, described in this paper, which measures triethyl lead as the complete mono-valent organo-lead ion has made it possible to demonstrate directly that tetraethyl lead is broken down to triethyl lead in rats in vivo. Triethyl lead appears to be stable in the body for at least four days (Table 3) so that any subsequent degradation to diethyl lead or inorganic lead takes place more slowly than the initial conversion of tetra- to tri-ethyl lead.

Although it was necessary to inject more tetraethyl lead than triethyl lead in order to kill rats, the amount of triethyl lead found in the brain was the same. This suggests that the toxicity of tetraethyl lead is due to its conversion to triethyl lead and only the latter is active.

Although tetraethyl lead is fat-soluble, triethyl lead is strongly water-soluble, as shown in Table 10, and yet it can be found in rat brain tissue in vivo and has a strong effect on brain slice metabolism in vitro.

It is possible that tetraethyl lead reached the brain in sufficient quantity to enable it to be converted to active concentrations of triethyl lead.

TABLE 10

DISTRIBUTION OF TRIETHYL LEAD CHLORIDE BETWEEN WATER AND VARIOUS SOLVENTS

\begin{tabular}{l|c}
\hline Solvent & $\mathbf{R}=$ Water/Solvent \\
\hline Chloroform & $38 \cdot 4$ \\
Benzene & $>100$ \\
Ether & $8 \cdot 0$ \\
Olive oil & $20 \cdot 8$ \\
\hline
\end{tabular}

$R$ is the quotient of the amount of triethyl lead in the water layer/the amount in the solvent layer. Each $R$ value is the mean obtained when $10 \mathrm{ml}$. portions of water containing a range of 35 to $150 \mu \mathrm{g}$. triethyl lead chloride were mixed with $10 \mathrm{ml}$. portions of a solvent.
However, this seems unlikely, not only from the analytical data for volatile lead mentioned above but also because when several rat tissues were tested in vitro for their ability to convert tetra- to triethyl lead no activity was found in brain whereas a very active system was present in liver. It may be concluded that tetraethyl lead is not concentrated in the brain but rather is converted by the liver to triethyl lead which is transported to the brain.

Experimental findings on the conversion of tetraethyl lead by liver preparations showed that the system has many features in common with the enzymic system(s) responsible for the metabolism of barbiturates, organophosphorus compounds, tetraethyl tin, and several other substances foreign to the body. The conditions which most closely simulate those present in vivo for the conversion activity of the liver are not known. The rate found with liver slices of $60 \mu \mathrm{g}$. triethyl lead/g. wet weight $/ \mathrm{hr}$. would be sufficient to account for the triethyl lead present in vivo four hours after injections of tetraethyl lead but the conversion activity was very much higher in fortified liver homogenate preparations where a rate of $190 \mu \mathrm{g}$. triethyl lead/g. wet weight/hr. was found.

The biochemical results obtained from studies in vitro on the action of tetra-, tri-, and di-ethyl lead and lead acetate on the metabolism of rat brain preparations show that there is a definite difference between the action of these four lead compounds. Tetraethyl lead and lead acetate are without effect when added to brain tissue in vitro. The negative results with lead acetate were in contrast to those of Dolowitz, Fazekas, and Himwich (1937) who found that the $\mathrm{O}_{2}$ consumption and glycolysis of brain tissue was inhibited $50 \%$ by lead acetate. The species used by them is not stated and the concentration of lead acetate added to the tissues was high, although, as the authors stated, most of the lead was precipitated by the chloride and phosphates of the suspending fluids. They suggested that the infinitesimal amount of lead that remained free was sufficient to produce effects on tissue metabolism. Since inorganic lead is known to be among the heavy metals which denature proteins, caution must be used when interpreting results where enzyme systems are exposed to high concentrations of such metals. In an experiment carried out in this laboratory using a rat brain homogenate preparation with glucose as substrate, the $\mathrm{O}_{2}$ consumption was found to be $20 \%$ inhibited by lead acetate at a concentration of $9 \times 10^{-4} \mathrm{M}$ but there was no inhibition at $4 \times 10^{-4} \mathrm{M}$.

The biochemical actions of diethyl lead dichloride and triethyl lead chloride are also different. The action of diethyl lead on brain brei preparations can 
be prevented by the addition of B.A.L. or thioglycollic acid showing that this compound has an affinity for SH compounds. Its biochemical behaviour resembles that of phenylarsenious acid, arsenite, and diethyl tin dichloride (Aldridge and Cremer, 1955). Triethyl lead has no affinity for thiol compounds. It is the most active of the four lead compounds against the metabolism of brain slices. Unpublished observations showed that slices of liver and kidney tissue were less sensitive to triethyl lead than brain. Although the action of triethyl lead on the metabolism of rat brain cortex slices is indicative of an impairment of glucose oxidation and consequently a reduction in the synthesis of highenergy phosphates, no experimental studies have as yet been made to confirm whether it has a similar action in vivo. The biochemical effects of di- and triethyl lead appear to be very similar to those of diand tri-ethyl tin respectively, and considerable detailed studies on the toxicity of di-and tri-alkyl tin compounds have been made in these laboratories as was recently reported by Barnes and Stoner (1958). The exact mode of action of triethyl tin is not yet known, but from the study on the metabolism of phosphate compounds in brain in vivo (Stoner and Threlfall, 1958) of rats injected with triethyl tin it seems that there is a failure in the utilization of chemical energy rather than in its production. A similar finding might be true for triethyl lead, but not necessarily because the signs of poisoning by the two compounds are not identical in rats in vivo.

It is important to note that tetraethyl lead is without effect on the metabolism of brain cortex slices when added in vitro, except at high concentrations. This negative effect provides almost conclusive evidence that the deranged metabolism of brain slices prepared from rats which have been given tetraethyl lead is due entirely to the triethyl lead shown to be present in the brains of these animals. Calculations made from Table 8 show the possibility of a correlation between the amount of triethyl lead found in the brains of animals injected with either tetra- or triethyl lead and the degree of alteration to the metabolism of brain slices.

From the chemical nature of tetraethyl lead it would not be expected to be a reactive compound in the body. However, its conversion to triethyl lead appears to be readily brought about by an enzyme system(s) in liver although the mechanism of the reaction is not known. The product, the monovalent triethyl lead ion, is biochemically active, particularly against brain tissue, and does not undergo rapid decomposition by the liver.

The effect of triethyl lead on brain metabolism appears to be due to its organic lead composition and not primarily to its lead content.
Studies on the metabolism of substances foreign to the body have shown that in many instances the product is more toxic than the original compound so that the term "detoxication mechanism" is not applicable. This seems to be the case for tetraethyl lead.

No effective treatment can be suggested for tetraethyl lead poisoning. Although SKF 525-A prevented the conversion in vitro of tetra- to tri-ethyl lead it has not been tested in vivo for possible therapeutic value. However, it did not prevent the conversion of tetrato tri-ethyl tin in rats in vivo (Cremer, 1958).

Kitzmiller, Cholak, and Kehoe (1954) treated men suffering from tetraethyl lead exposure with ethadamil-calcium-disodium (the calcium salt of E.D.T.A.) and compared its effectiveness with B.A.L. They found that no valid conclusions could be drawn as to the useful therapeutic effects, but both substances increased the output of inorganic lead in the urine. Since it has been shown in this paper that triethyl lead does not combine with either E.D.T.A. or B.A.L. it is unlikely that they would be effective in preventing its action. A substance which did combine avidly with triethyl lead might prove to have more therapeutic value in tetraethyl lead poisoning.

I wish to thank Dr. P. R. Boyd of the Associated Ethyl Company Ltd. for his kind cooperation and for supplying tetra-, tri-, and di- ethyl lead, Mr. D. Potter for invaluable technical assistance, and Dr. P. N. Magee for examining the histological preparations.

\section{REFERENCES}

Aldridge, W. N., and Cremer, J. E. (1955). Biochem. J., 61, 406. Barker, S. B., and Summerson, W. H. (1941). J. biol. Chem., 138, 535.

Barnes, J. M., and Stoner, H. B. (1958). Brit. J. industr. Med., 15, 15. Bischoff, F., Maxwell, L. C., Evans, R. D., and Nuzum, F. R. (1928). J. Pharmacol. exp. Ther., 34, 85.

Brodie, B. B. (1956). J. Pharm. (Lond.), 8, 1.

Brodie, B. B. (1956) J. Pharm. (Lond.), 8, 1. . Bruce, H. M., and Parkes, A. S. (1956). J. Anim. Tech. Ass., 7, 54. 38, 161 .

Calvery, H. O., Laug, E. P., and Morris, H. J. (1938). Ibid., 64, 364. Cassells, D. A. K., and Dodds, E. C. (1946). Brit. med. J., 2, 681. Cremer, J. E. (1957). Biochem. J., 67, 87.

(1958). Ibid., 68, 685.

Dolowitz, D., Fazekas, J. F., and Himwich, H. E. (1937). J. industr. Hyg., 19, 93.

Friedemann, T. E., and Haugen, G. E. (1943). J. biol. Chem., 147, 415 .

Harnack, E. (1878). Naunyn-Schmiedeberg's Arch. exp. Path. Pharm., 9, 152.

Kehoe, R. A., and Thamann, F. (1931). Amer. J. Hyg., 13, 478.

Kehoe, R. A., and Thamann, F. (1931). Amer. J. Hyg., 13, ${ }_{\text {A.M.A. }}$ Arch. industr. Hyg., 10, 312.

Machle, W. F. (1935). J. Amer. med. Ass., 105, 578.

Magee, P. N., Stoner, H. B., and Barnes, J. M. (1957). J. Path. Bact. $73,107$.

Mason, E. C.. (1921). J. Lab. clin. Med., 6, 427.

Morelli, A., and Preziosi, P. (1953). Folia med. (Napoli), 36, 526.

Mortensen, R. A. (1942). J. industr. Hyg. 24, 285.

Schneider, W. C. (1948). J. biol. Chem., 176, 259.

Stadie, W. C., and Riggs, B. C. (1944). Ibid., 154, 687.

Stoner, H. B., Barnes, J. M., and Duff, J. I. (1955). Brit. J. Pharmacol., 10, 16.

- and Threlfall, C. J. (1958), Biochem. J., 69, 376

Umbreit, W. W., Burris, R. H., and Stauffer, J. F. (1951). Manometric Techniques and Tissue Metabolism, p. 119. Burgess

Weil, C. S. (1952). Bo., Miometrics, 8, 249. 